International Journal of Engineering \& Technology, $7(3.29)(2018) 134-137$
SPC
International Journal of Engineering \& Technology
Website: www.sciencepubco.com/index.php/IJET
Research paper

\title{
Effectivity of kiwi and sukamahi dam on jakarta flood control
}

\author{
Airlangga Mardjono $^{1 *}$, Pitojo Tri Juwono ${ }^{1}$, Lily Montarcih Limantara ${ }^{1}$, Ery Suhartanto ${ }^{1}$ \\ ${ }^{1}$ Water Resources Engineering, Faculty of Engineering, Brawijaya University, Malang, Indonesia commission on Large Dam (Inac- \\ old), Jakarta, Indonesia \\ *Corresponding author E-mail: ariemardjono234@yahoo.com
}

\begin{abstract}
Various infrastructures such as flood levees, dams and reservoirs of flood control began to be developed in the 19th century to the 20th century. These buildings are very effective in controlling the flow of rivers and preventing flood waters from entering residential areas located in flood-prone areas. Flooding in urban areas has a huge impact, covering all aspects of life as well as on the landscape. Ciliwung is one of the rivers that allegedly contributed to the problem of flood in Jakarta, various engineering done on Ciliwung to help control flooding in Jakarta. One of the engineering done is the construction plan of Ciawi Reservoir and Sukamahi Reservoir. In this research, the writer performed the flood calculation using Nakayasu while method of flooding is calculated using the pool routine level method. The effectiveness of these two reservoirs can be determined by simulating floods in the existing condition and comparing them with the flood simulation after the construction of the dam. The final test of this research is to determine the effectiveness level of Ciawi and Sukamahi dam infrastructure in reducing flood volume in Jakarta.
\end{abstract}

Keywords: Effectivity; Flood Infrastructure; Flood Simulation; Pool Routing Level

\section{Introduction}

Jakarta is the capital city of Indonesia, the city is located between 5 '19'12 " - 6 ${ }^{\circ} 23^{\prime} 54$ "LS and 106 22'42" - 106 ${ }^{\circ} 58^{\prime} 18$ "East longitude with an average height of approximately 7 ASL (Above the sea level). Jakarta has an area of $\pm 664 \mathrm{~km} 2$ with a population of 9.6 million inhabitants who are in 2.2 million families in 2010[1]. As the administrative, governmental and economic center, Jakarta has developed very rapidly to the surrounding buffer zone. The Ciliwung River is one of 13 rivers that passes through Jakarta and empties into the Java Sea. In addition, this river is a very influential river in Jakarta. Ciliwung has a river length of $120 \mathrm{~km}$, with a watershed area of $400 \mathrm{~km} 2$. The Ciliwung watershed is one of the watersheds in Indonesia that falls into the watershed category with critical condition [2]. This is due to the transfer of land function in the upstream area from its initial function is as a catchment area into tourist areas and settlements.

Of the 13 rivers flowing in DKI Jakarta, the Ciliwung River has the greatest impact during the rainy season as it flows across many villages, densely populated housing, and slums. From population statistics of DKI Jakarta, it is known that the people who live on the banks of the River Ciliwung for 350,000 people with the number of buildings as many as 70,000 units. The river is considered a river that suffered the worst damage compared to other rivers in Jakarta and has the potential to cause flooding in Jakarta.

Flood is one of the disaster that almost every year hit Jakarta. The largest floods that occurred in the last decade occurred in 2007. This flood inundated more than $40 \%$ of Jakarta City, 80 people died and 340,000 were displaced [3]. Various efforts have been made by the government in flood prevention, both structurally and non-structurally. Structurally flood control systems in the Ciliwung River include the creation of a number of flood wire or flood observation posts. In addition, prevention of flood flooding to certain heights with embankments, as well as lowering the flood water level with normalization, sludge, canal flood, and interconnection. The core concept of the canal flood is the control of water flow from upstream and regulate the volume of water entering Jakarta. In addition, the government is also working to minimize flood discharge with reservoirs, as well as to reduce puddles with polders, pumps and drainage systems.

The main problem in controlling rainfall runoff in urban areas generally consists of the need to control peak discharge and flow depth throughout the system, in order to avoid undesired puddles. Peak discharge is a commonly chosen alternative. These additives have the added benefit of allowing for infiltration and evaporation so that in addition to reducing peak discharge also minimizes runoff volume. Temporary in-situ or pool-like containers as well as a sediment container, can also serve as a means of controlling water quality.

Many studies and flood control efforts have been undertaken to reduce the flood loss occurring in Jakarta. Ciawi and Sukamahi Dam is one of the infrastructure designed by the government to reduce the peak flood and increase the peak flood time in Jakarta. Dry Dam Ciawi and Sukamahi are the first dry dams built in Indonesia. Dry dams can be used to temporarily withstand excess water during floods and freely deliver during normal conditions [4]. The purpose of this study is to calculate the effectiveness of the construction of Ciawi and Sukamahi reservoirs as one of the infrastructures that will function as one of the means to reduce the flood peak in Jakarta.

\section{Study area description}

Astronomically, the Ciliwung River is located at $6^{\circ} 05^{\prime}-6^{\circ} 50$ 'LS and $106^{\circ} 40^{\prime}-107^{\circ} 00^{\prime}$ BT. The Ciliwung River Basin area is limited by 
the Cisadane River Basin on the west and the Citarum River Basin on the east.

From population statistics of DKI Jakarta, it is known that the people who live on the banks of the River Ciliwung for 350,000 people with the number of buildings as many as 70,000 units. The river is considered a river that suffered the worst damage compared to other rivers that flow in Jakarta.

Administratively, the location of the Ciawi Dam is located in the upper part of the Ciliwung River in Ciawi Village, Megamendung Sub-district, Bogor Regency.

The Sukamahi Dam is located on the Cisukabirus River in Sukatil Village, Megamendung Sub-district, Bogor Regency. Geographically, Ciawi Dam is located at $106^{\circ} 52^{\prime} 20$ "East Longitude, $06^{\circ} 39^{\prime 2} 28^{\prime \prime}$ South Latitude, Sukamahi Dam is located at $106^{\circ} 52^{\prime} 20$ "East Longitude, 060'12" South Latitude.

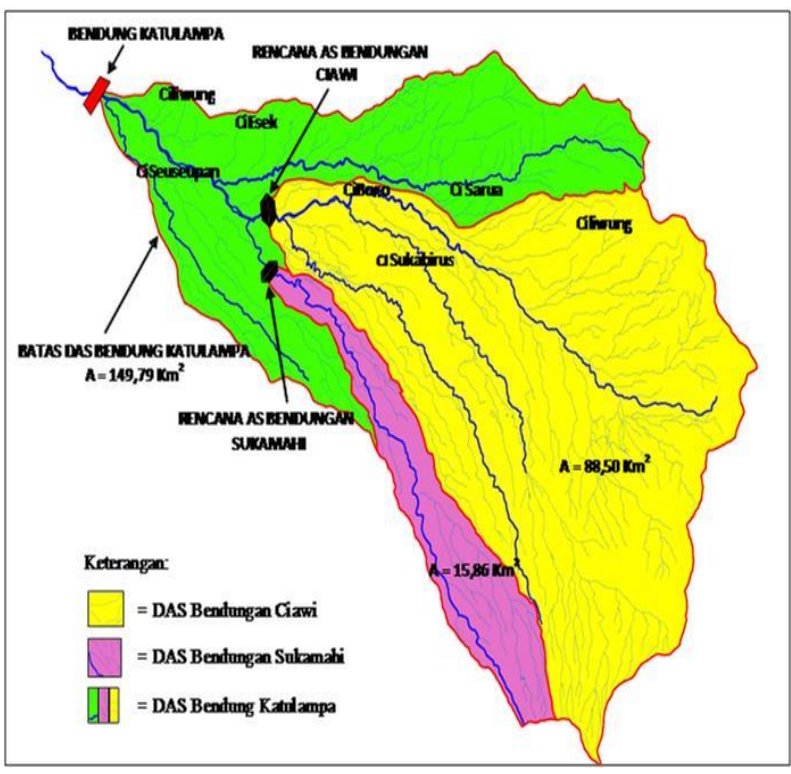

Fig. 1: Watershed Division.

\section{Basic theory}

The use of HSS Nakayasu method requires some characteristics of the parameters of the stream region, as follows [5]:

$\mathrm{R}=1-(1-\mathrm{P})^{\mathrm{n}}$

With $\mathrm{P}$ acting as time of peak, time lag, time base of hydrograph, watershed area, or length of longest channel. The formula to Nakayasu unit hydrograph is:

$Q_{p}=\frac{C \cdot A \cdot R_{0}}{3.6\left(0.3 T_{p}+T_{0.3}\right)}$

With

Q_p: Flood peak discharge $(\mathrm{cms})$

R_0: Unit rainfall (mm)

T_p: Peak time (hour), formulated with $\mathrm{t} \_\mathrm{p}=\mathrm{t} \_\mathrm{g}+0.8 \mathrm{t} \_\mathrm{r}$

T_0.3: Time required to reach $30 \%$ of peak flow (hour), formulated with T_0.3= a.t_g

A: Drainage area $(\mathrm{km} 2)$

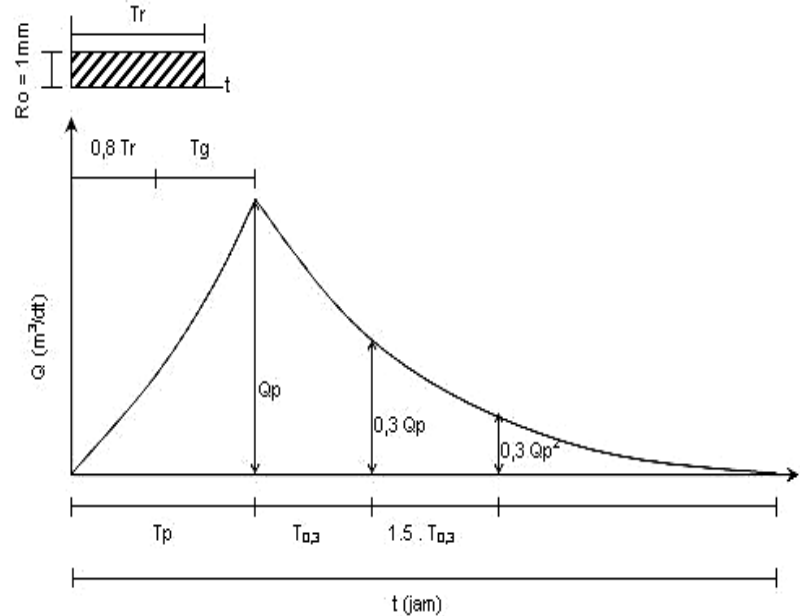

Fig. 2: Nakayasu Unit Hydrograph.

Value of $\alpha$ at peak time equation depend on the flood characteristic [6]. Flood tracking through a reservoir is conducted to determine the effect of the discharge that enters the reservoir at a time against the discharge out through the reservoir at the same time. Water stored in a reservoir is removed through the reservoir through a spill system located on the dam body. The spill system on this dam may use a bottom outlet, a top weir system, or a combination of the two spill systems. Before performing flood tracking, a rating system of the spillway is firstly assessed to determine the relationship between the water level in the reservoir and the outflow through the spill system.

The level pool routing is a procedure for calculating the outflow hydrograph of a flat-faced reservoir, wherein the given inputs are inflow hydrograph and storage-outflow characteristics. Based on the following continuity equations [6]:

$\frac{d S}{d t}=I(t)-Q(t)$

If the variation of the inflow and outflow at an interval is estimated to be linear, then the change in storage at the interval, $\mathrm{Sj}+1-\mathrm{Sj}$, can be determined by rewriting the above equation to be:

$S_{j+t}-S_{j}=\frac{I_{j}+I_{j+2}}{2} \Delta t-\frac{Q_{j}+Q_{j+1}}{2} \Delta t$

In principle. The calculation used to approach the discharge going through the spill system is to use the principle of conservation of mass. The approximate formula for knowing the flowing discharge in this system at any water level is:

$Q=C_{d} \cdot A \cdot V$

Where:

Q: Discharge through bottom outlet (cms)

C_d: Discharge coefficient (0.6)

A: Intake area of bottom outlet $(\mathrm{m} 2)$

V: Water velocity through bottom outlet $(\mathrm{m} / \mathrm{s})$

The overflow system allows water to flow and to melt through the shrubs of a dam or dam. To know the relationship between water level with discharge discharge can be used formula:

$Q=C_{d} \cdot L \cdot h^{3 / 2}$

Where:

Q: Discharge over the weir $(\mathrm{cms})$

C_d: Discharge coefficient (1.28)

L: Weir width $(\mathrm{m})$

$\mathrm{H}$ : Water height above the weir $(\mathrm{m})$ 


\section{Methodology}

As for the methodology used in this research, it will be explained here.

The first step to be done is to gather required data, such as thematic maps, especially that of upper Ciliwung area. The thematic maps should cover land use distribution, digital elevation model, river, and such. These maps are needed to determine the boundary of the watershed.

After determining the boundary, it is necessary to determine the properties of the watershed, such as slope, land use distribution, and area. Another information that should be gathered is the rainfall data from rainfall gages around the watershed which has influences over the watershed area. The combination of those data can produce the proper result for effectiveness calculation of Ciawi and Sukamahi Dam in Ciliwung River.

The complete steps for this research is in the following flowchart:

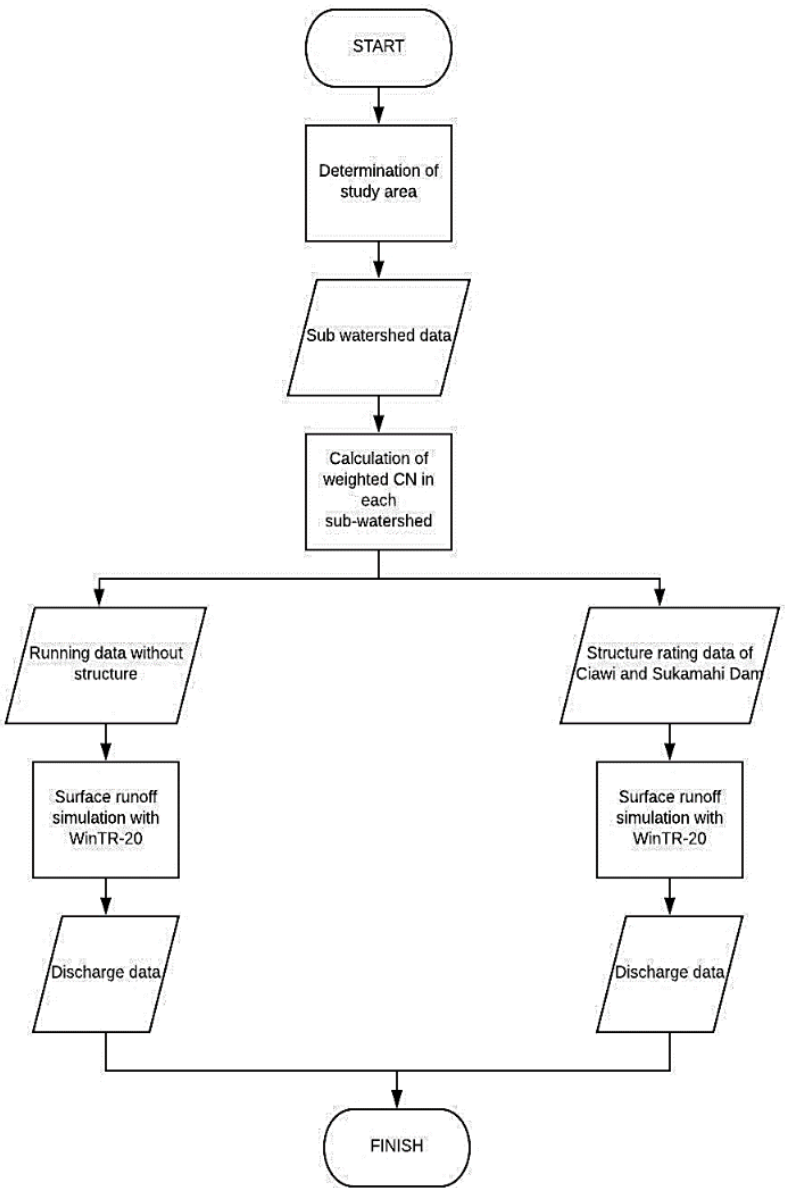

Fig. 3: Research Flowchart.

\section{Results and discussions}

From the results of flood calculations with return period of 100 years at 3 points ie Ciawi dam. as Sukamahi Dam and the water gate of katulampa. The resulting flood discharge on Ciawi Dam for $546.20 \mathrm{cms}$. Sukamahi Dam $143.22 \mathrm{cms}$ and At Water Gate Katulampa of $734.51 \mathrm{cms}$.

Table 1: Summary of Simulation

\begin{tabular}{lllll}
\multicolumn{5}{c}{ Table 1: Summary of Simulation } \\
\hline & Discharge & & \\
\hline & $\begin{array}{l}\text { Inflow } \\
(\mathrm{cms})\end{array}$ & $\begin{array}{l}\text { Outflow } \\
(\mathrm{cms})\end{array}$ & $\begin{array}{l}\text { Flood reduc- } \\
\text { tion }(\mathrm{cms})\end{array}$ & $\begin{array}{l}\text { Effectiv- } \\
\text { ity }(\%) \\
12.38\end{array}$ \\
$\begin{array}{l}\text { Ciawi Dam } \\
\text { Sukamahi }\end{array}$ & 546.20 & 478.56 & 67.64 & 18.26 \\
$\begin{array}{l}\text { Dam } \\
\text { Katulampa }\end{array}$ & 143.22 & 117.07 & 26.15 & 9.56 \\
Weir & 734.51 & 664.32 & 70.19 & \\
\hline
\end{tabular}

Hydrographs of flood tracking results at Katulampa gates that can show the effectiveness of the two infrastructures development can be seen in the following graph.

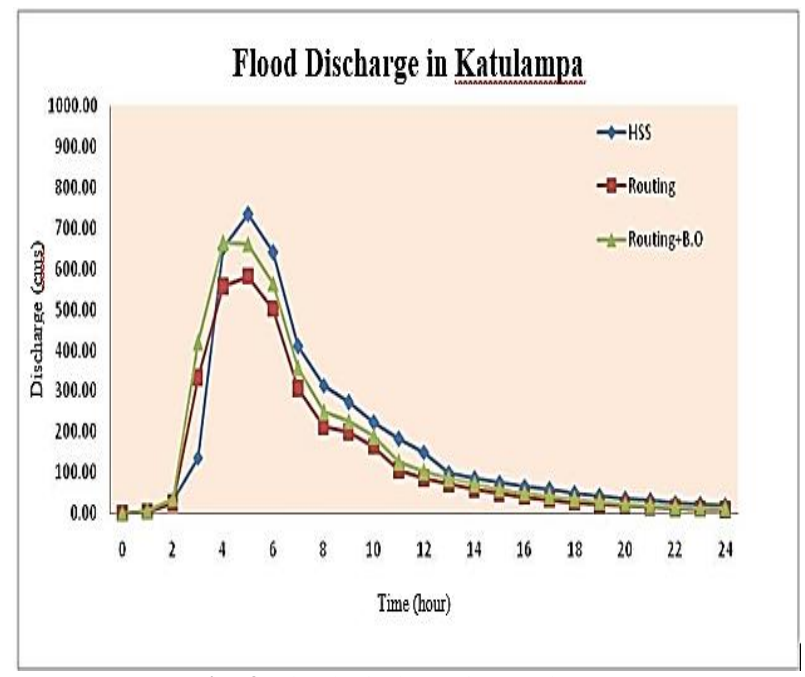

Fig. 4: Flood Discharge in Katulampa.

The maximum reduction rate of flood intensity that will occur in Jakarta area in Ciliwung watershed is $9 \%$. Based on the terminology theory of Integrated Stormwater Management Plan (ISMP) [7] has been well recognized by local governments as well as by various agencies working in the environment agencies in British Columbia, Canada. ISMP is used as a tool for planning rainwater management and its runoff with a comprehensive and integrated approach as illustrated in the following diagram.

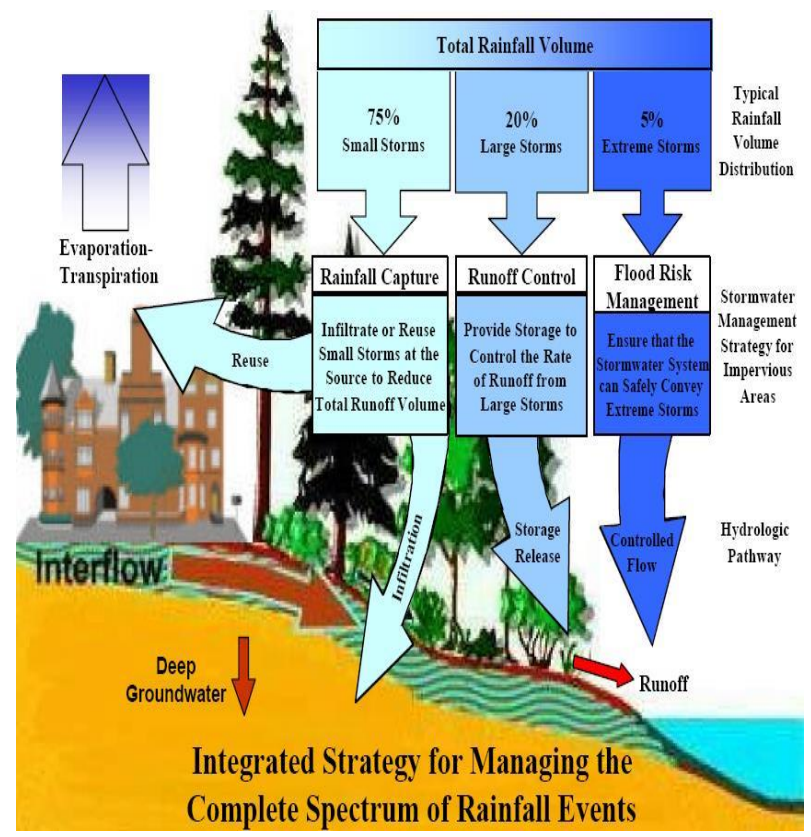

Fig. 5: Integrated Strategy of Storm Water Management.

Land development innovation and rainfall management, with catchment area-based ecosystem approach [8] is a new paradigm in rainfall management system that is expected to improve flood mitigation effectiveness. Appropriate as described in the following table: 


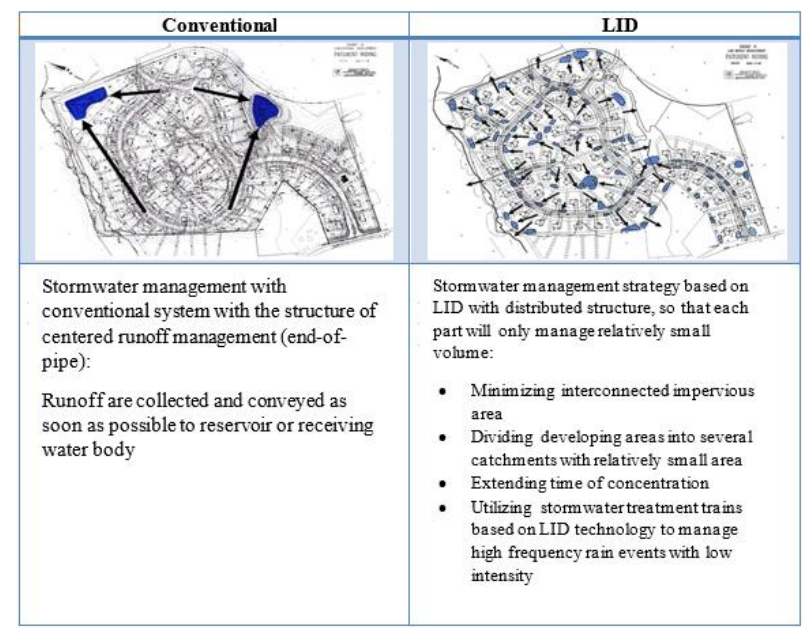

Fig. 6: LID Concept.

\section{Conclusion}

The above flood calculations are then routed with methods that generate outflow discharge at each dam is $478.56 \mathrm{cms}$ at Ciawi and $117.07 \mathrm{cms}$ on Sukamahi. Therefore. the effectiveness of the Dam to the Flood Debit with 100-year return period of $11.56 \%$ at the Ciawi Dam and $18.25 \%$ at the Sukamahi Dam.

After routing on both dams. then the flood discharge at the Katulampa weir become $664.32 \mathrm{cms}$ from $734.51 \mathrm{cms}$ with flood reduction value $70.19 \mathrm{cms}$ and the effectiveness $9.56 \%$

Based on the results of this study, researchers will conduct further research that is by trying to apply the theory of integrated rainfall management using GIS (Geographic Information System) to map the spread of reservoirs in sub-sub areas. Planning of dam infrastructure with spatial distribution is expected to assist the process of flood reduction due to the placement of retention ponds in accordance with the basic concept of Low Impact Development. The simulation was done by lump model; difference approach of hydrological model must be simulated for the next research. Based on the previous research that noted that the difference of distributed and lump model can't be neglecting depended on the rainfall organization over the watershed [10].

\section{References}

[1] Abidin. H., D. Darmawan., et al. "Land subsidence of Jakarta (Indonesia) and Its Geodetic Monitoring System." Land subsidence of Jakarta (Indonesia) and Its Geodetic Monitoring System (Natural Hazard) 23. 2010

[2] Wira Yudha, Bakti. "Prediksi Laju Erosi Potensial Dan Laju Timbulan Sampah Potensial pada Luasan Penutup Lahan Kedap Air (Studi Kasus DAS Ciliwung) Berbasis Sistem Informasi Geografis (SIG)". Depok: Universitas Indonesia. 2015.

[3] Brinkman, JanJaap and Hartman. "Jakarta Flood Hazard Mapping Framework." Jakarta. 2008.

[4] Lempérière. F. "The role of dams in the XXI century, achieving a Sustainable Development Terget." (Hydropower and Dams). 2006.

[5] Soemarto, CD. "Hidrologi Teknik". Surabaya: Usaha Nasional. 1986.

[6] Chow V., Maidment. “Applied Hydrology”. Mc. Geow Hill International. 1988 .

[7] Pollution, Ministry of Water Land and. "Stormwater Planning: A Guidebook for British Columbia”. 2002.

[8] LID, Massachusetts. "Low Impact Development Principles, Techniques, and Implementation.” 2009. 